УДК 378.091.2:004.77

DOI:

Наталія Яремчук, кандидат педагогічних наук, доиент кафедри загальної педагогіки та педагогіки вищої школи Львівського національного університету імені Івана Франка

Назар Сениця, магістр Львівського національного університету імені Івана Франка

\title{
ПЕДАГОГІЧНІ УМОВИ ФОРМУВАННЯ ВІРТУАЛЬНОГО ОСВІТНЬОГО ПРОСТОРУ ЗАКЛАДУ ВИЩОЇ ОСВІТИ
}

Запропоновано авторське поняття "педагогічні умови формування віртуального освітнього простору (ВОП) закладу вищуої освіти”, їх визначено (формування ВОП на засадах особистісно зорієнтованого та компетентнісного підходів; створення навчально-методичного забезпечення до електронних навчальних курсів (“масових відкритих онлайн курсів”) та інноваційних методів і форм навчання в умовах ВОП; розвиток самостійної діяльності студентів в умовах ВОП; готовність студентів до дистаниійного (онлайн) навчання в умовах освітнього простору 3ВО) та здійснено детальний аналіз.

Ключові слова: віртуальний освітній простір закладу вищої освіти; інформаційно-цифррові технологї; дистанційне навчання; освітні онлайн платформи; віртуальний університет; педагогічні умови.

Jim. 10.

Nataliya Yaremchuk, Ph.D.(Pedagogy), Associate Professor of the General Pedagogy and Pedagogy of High School Department Ivan Franko National University of Lviv Nazar Senytsia, Master's degree Ivan Franko National University of Lviv

\section{PEDAGOGICAL CONDITIONS FOR THE FORMATION OF A VIRTUAL EDUCATIONAL SPACE OF A HIGHER EDUCATION INSTITUTION}

The concept "pedagogical condition" is analyzed and the author's concept of "pedagogical conditions for the formation of the virtual educational space of a higher education institution" is proposed. New definitions have been coined: 1) formation of the virtual educational space based on personality-oriented and competence-based approaches. 2) creation of educational and methodological support for e-learning courses ("public online courses") and innovative methods and forms of training in the conditions of virtual educational space; 3) development of the independent activity of students in the conditions of virtual educational space 4) readiness of students for distance (online) learning in the educational space of a higher education institution. A special feature of the first pedagogical condition is the realization of a person-oriented approach in the virtual educational space of higher education as an opportunity to form an individual educational space of a student in accordance with his cognitive needs, development of abilities, and creative activity. The competence approach is represented by the peculiarities of presenting competencies in educational programs and the specifics of their formation in the virtual educational space. The second pedagogical condition reveals the methodology of creating an electronic training course, the structure of mass open online courses, the features of introducing innovative methods and forms of training, in particular, the use of electronic textbooks, blogs (video blogs), webinars, social media, gamification, virtual simulators (VR technologies), etc. The third pedagogical condition determines the fundamental aspects of independent work of students in the virtual educational space. Under such conditions, the process of learning/self-study is active, where the student himself builds an individual educational trajectory, acquiring knowledge not only within the framework of formal, but also non-formal education (maintaining personal blogs and Telegram channels, participating in online forums and educational communities, watching webinars, video lectures, etc.). The fourth pedagogical condition is defined as the readiness of students to learn in the changing realities of the virtual educational space, the effectiveness of which is considered through the components of the structure, factors, criteria, indicators and levels.

Keywords: virtual educational space of a higher education institution; information and digital technologies; distance learning; online educational platforms; virtual university; pedagogical conditions.

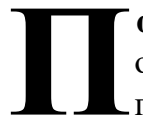
остановка проблеми. Сьогодні освіта синхронно реагує на еволюційні перетворення соціально-інформаційних процесів, розв'язуючи багатофакторні завдання щодо побудови інформаційно-цифрового освітнього простору відповідно до віртуальної освітньої системи. Актуальними поняттями освітньої практики стали цифрові технології, 


\section{ПЕДАГОГІЧНІ УМОВИ ФОРМУВАННЯ ВІРТУАЛЬНОГО ОСВІТНЬОГО ПРОСТОРУ ЗАКЛАДУ ВИЩОЇ ОСВІТИ}

освітні платформи, масові відкриті онлайн курси, смарт-освіта, соціальні мережі як освітній ресурс, віртуальні кампуси, ВР-технології, вебінари, які, безумовно, вимагають системного укладу відповідно до теоретико-методологічних та організаційно-методичних засад освітнього процесу вищої школи.

Передумовою формування віртуального освітнього простору була технологія дистанційного навчання, яка у поєднанні 3 інформаційними та цифровими технологіями, забезпечила новий формат освітніх послуг. Виникає запит на нові підходи до побудови процесу віртуального навчання; методи віртуального навчання; форми організації віртуального навчання; технології віртуального викладання та учіння, а також грунтовний аналіз педагогічних умов. Забезпечуючи певний перелік вимог до освітнього простору, саме педагогічні умови забезпечують моделювання процесу формування та проєктування шляхів впровадження віртуального освітнього простору у практичні реалії системи освіти.

Аналіз основних досліджень і публікацій. Багатоаспектність дослідження феномену віртуального освітнього простору присутня у низці наукових досліджень. Вплив віртуальної освіти на процес професійного становлення фахівця в умовах формальної та неформальної освіти розглядали Б. Гершунський, А. Єршов, А. Артюхина, Л. Ахметов, Н. Багдасарьян, А. Богомолов, Я. Ваграменко, О. Великосельский, М. ВайндорфСисоєва, Б. Гамбург, В. Глушков, В. Грицик, А. Денисова, В. Зінченко, А. Кушніренко, І. Лапшина, Р. Лубков, Л. Міщенко, В. Монахов, В. Михалевич та ін.). Відповідно до особливостей дистанційного навчання проблему досліджували: М. Бершадський, В. Меламуд, Е. Полат, В. Солдаткін, Г. Троян та ін.

Отже, елементи віртуального навчання загалом аналізуються в умовах дистанційного навчання, а поодиноке наукове представлення віртуального освітнього простору немає системного наукового узагальнення в науковометодичній літературі. Очевидний запит на освітню послугу в умовах віртуального освітнього простору студентів, вимагає розгляду даної проблеми у теоретико-методологічних та організаційно-методичних аспектах.

Мета статті - визначити та обгрунтувати педагогічні умови формування віртуального освітнього простору закладу вищої освіти.

Виклад основного матеріалу. Багатовекторна актуальність феномену “віртуальний освітній простір” вимагає фундаментального аналізу його педагогічних умов. Забезпечуючи певний перелік вимог до освітнього простору, саме педагогічні умови забезпечують моделювання процесу формування та проєктування шляхів впровадження віртуального освітнього простору у практичні реалії системи освіти.

Зважаючи, що визначальним пріоритетом у формуванні освітнього простору є створення умов для самовизначення та самореалізації особистості, то віртуальний освітній простір 3ВО спрямований на забезпечення таких умов для професійного та особистісного становлення фахівця у площині віртуальної реальності із функціональним ресурсом інформаційно-цифрових технологій.

Проаналізуємо декілька визначень поняття “педагогічна умова” для правильної змістової інтерпретації в контексті нашого дослідження.

У науково-довідковій літературі із професійної освіти педагогічні умови визначають як “обставини, від яких залежить та відбувається цілісний продуктивний педагогічний процес професійної підготовки фахівців, що опосередковується активністю особистості" [3].

На думку Н. Горої, “поняття "умова" розуміється як сукупність певних, фактів, обставин, впливів, процесів, що надають змогу управляти навчально-творчим процесом в результаті якого формується особистість" $[2,135]$.

У своєму дослідженні О. Єжова, “умови” виокремлює від “фактів”, оскільки умова є обставинний інструментарій, дія якого впливає на створення або зміну явища, процесу, системи [5, 39-43]. Низка умов, яка визначає їхню сукупність формує змінне середовище, у якому відбувається оптимальне поліпшення, щодо змісту, методів, форм організації відповідно до мети. Отже, щоб отримати результат, необхідно впливати на дієвість процесу, явища чи системи. Науковиця, досліджуючи педагогічні умови педагогічного процесу, аналізувала його структурні компоненти - цільовий, мотиваційний, змістовий, операційнодіяльнісний, контрольно-оцінковий. Такий науковий підхід близький нашому дослідженні, проте оцінка педагогічного та освітнього процесу відповідають лінійній траєкторії розвитку, а освітній простір тяжіє до просторово-предметного виміру, у якому важливі умови для самовираження та самореалізації особистості кожного студента. Це визначає інший підхід до формування обставинних впливів на досліджуване явище.

Категорія “педагогічні умови” $є$ різноплановою та багатоаспектною. Вплив на відповідні обставини освітнього явища, процесу чи системи залежать від області дослідження - психологічної, методологічної, технічної, управлінської, методичної; теоретичної чи прикладної. 


\section{ПЕДАГОГІЧНІ УМОВИ ФОРМУВАННЯ ВІРТУАЛЬНОГО ОСВІТНЬОГО ПРОСТОРУ ЗАКЛАДУ ВИЩОЇ ОСВІТИ}

Відповідно, в межах нашого дослідження можна розглядати різні класифікації педагогічних умов: психолого-педагогічні, організаційно-методичні, соціально-педагогічні. Найбільш конструктивний і результативний підхід формують організаційнометодичні умови, які визначаються як потенційні можливості, обставини, суб'єктивний взаємозв'язок чи педагогічна взаємодія, що відображається у змістових, дидактично-процесуальних та методичних аспектах.

Цікавим та раціоналістичним дослідженням методологічних аспектів організаційнопедагогічних умов є дисертаційне дослідження О. Галкіної. Науковиця дає комплексну оцінку аналізованого у статті явища на основі власної генези дослідження. Організаційно-педагогічні умови можна розглядати як [1]: показник ефективності внутрішньої структури освітнього простору (середовища) як передумови до активних організаційних змін; організаційнорозпорядчі заходи та ресурси, що їх забезпечить (комплектація навчальних спільнот, режим організації освітньої діяльності закладу); низка обставин, пов'язаних між собою, що передбачають системне управління (проєктування) освітнім простором; супровідні обставини, які забезпечують формування освітнього простору відповідно до поставленої мети.

Аналізуючи особливості формування віртуального освітнього простору через виокремлення й обгрунтування педагогічних умов, які б забезпечили оптимальну конструкцію на інституціональному рівні, важливо розглянути потенціал освітнього простору через категорію організації. Зважаючи, що організацію слід розглядати в контексті системного утворення, в якому цілісно і впорядковано об'єднані ресурси (людські, технічні, навчальні), які через налагодження взаємозв'язків суб'єктів та управління (самоуправління) ними, забезпечують функціональність інституції у реалізації освітньої програми. Відповідно до інституційного рівня, будь-яку організацію слід розглядати 3 позиції внутрішніх та зовнішніх зв'язків, тому педагогічні умови повинні відповідати ефективності реалізації освітньої програми “внутрішніми” студентами 3ВО та “зовнішніми” студентами, які $\epsilon$ замовниками віртуальної освітньої послуги формальної чи неформальної освіти. Отже, педагогічні умови формування віртуального освітнього простору ЗВО необхідно розглядати 3 позиції функиіональності ресурсів (людських технічних) у їхній безпосередній та опосередкованій взаємодії, навчально-методичного забезпечення освітніх програм, електронних навчальних курсів, діагностики готовності студентів до навчання в умовах дистанційного (онлайн) навчання. Такі аспекти організаційнометодичних умов забезпечують причиновонаслідкові зв'язки між потребою формування віртуального освітнього простору ЗВО і якісною освітньою послугою в системі вищої освіти. Якщо педагогічні умови правильно сформовані та реалізовані у формотворчому процесі віртуального освітнього простору, то якісним результатом $\epsilon$ самореалізований студент, який досягнув бажаної пізнавальної мети у професійному й особистісному становленні, змотивований до навчальної діяльності та перспективними планами щодо подальшого удосконалення у розкритті особистісного потенціалу.

Відповідно до проаналізованих теоретикометодологічних аспектів категорії “педагогічні умови” у контексті особливостей віртуального освітнього простору 3ВО, нами сформоване авторське визначення означеного явища.

Педагогічні умови формування віртуального освітнього простору $3 В О$ розуміються як фактори впливу на освітній процес, функціонування якого забезпечується інформаційно-цифровими технологіями та суб'єктами педагогічної взаємодії в межах 3ВО і глобального простору віртуальних освітніх послуг 3 метою особистісного та професійного становлення майбутніх фахівців, наукової діяльності академічних спільнот і формування суспільних культурно-ціннісних орієнтирів.

Проаналізуємо особливості нами виокремлених педагогічних умов.

Першою педагогічною умовою є формування віртуального освітнього простору на засадах особистісно зорієнтованого та компетентнісного niдходів. Формування освітнього простору ЗВО у своєму вихідному положенні спрямоване на створення умов для самовизначення та самореалізації особистості студента, його всебічного й гармонійного розвитку, що відповідає ідеї особистісно орієнтованого підходу. Його можливості визначаються низкою принципів: суб'єктивною позицією студента в освітньому просторі 3ВО; відповідність організаційнометодичного забезпечення особливостям особистісного та професійного становлення студента; співвідношення змісту освіти із професіограмою майбутнього фахівця; превентивність змісту навчальних курсів до становлення фахових компетентностей.

Сформоване авторське бачення вихідних положень особистісно орієнтованого підходу має відображення у теоретико-практичних засадах віртуального освітнього простору. 


\section{ПЕДАГОГІЧНІ УМОВИ ФОРМУВАННЯ ВІРТУАЛЬНОГО ОСВІТНЬОГО ПРОСТОРУ ЗАКЛАДУ ВИЩОЇ ОСВІТИ}

Реалізація цього підходу у віртуальному освітньому просторі вищої освіти розглядається нами як можливість формування індивідуального освітнього простору студента відповідно до його пізнавальних потреб, розвитку здібностей, творчої активності. У контексті цього, освітні програми iз підготовки фахівців повинні передбачати гнучкість організації віртуального навчального процесу, варіативність електронних навчальних курсів, інтеграцію формальної та неформальної освіти.

Отже, особистісно орієнтований підхід до навчання студентів в умовах віртуального освітнього простору ЗВО зумовлений специфікою комунікативної взаємодії між викладачем та студентом, вибором студентом електронних навчальних курсів відповідно до потреб особистісного та професійного розвитку.

Сучасна підготовка фахівця в умовах 3ВО здійснюється на засадах компетентнісного підходу. Відповідно до запиту ринку праці, сучасний випускник $3 \mathrm{BO}$ повинен бути затребуваний та конкурентоспроможний. Такого результату можна очікувати за умови формування у студентів ключових (базових, особистісних) та предметних (фахових, спеціальних) компетенцій, які передбачають результат навчання у дієвості знань та осмисленні умінь практичного самовираження студента у розв'язанні завдань професійного спрямування. Загалом, в освітніх програмах підготовки спеціалістів передбачене відображення відповідних компетентностей, проте їхнє формування в умовах віртуального освітнього простору передбачає можливі ризики. Вважаючи, що освітня програма є комплексним і системним утворенням щодо змісту, форм i методів втілення, то особливості віртуального навчання не мають чітких рамок дієвості, опираючись на дорадчий характер рекомендації щодо іiї встановлення. Власне в цьому i розкривається дисонанс проблеми віртуального освітнього простору ЗВО - професійна підготовка фахівця як комплексне системне утворення, що відповідає компетентнісному підходу, та отримання знань з електронних навчальних курсів як освітніх пропозицій глобального освітнього простору.

Другою педагогічною умовою є створення навчально-методичного забезпечення до електронних навчальних курсів (“масових відкритих онлайн курсів”) та інновачійних методів $i$ форм навчання в умовах віртуального освітнього простору.

Побудова процесу навчання в умовах віртуального освітнього простору переорієнтовує структуру процесу навчання у дистанційну комунікативну педагогічну взаємодію між викладачем і студентом (“навчальним середовищем”, “віртуальним кампусом”) у здобутті знань та формування компетентностей відповідно до навичок користування інформаційним освітнім середовищем і тих педагогічних технологій, які формують результат навчальної діяльності студента.

Погоджуємось, що використання інформаційноцифрових технологій у навчальному процесі повинно забезпечуватись методичним супроводом. Студент, володіючи науковою інформацією, не завжди може нею скористатись і перетворити її на знання, необхідно створювати умови для їх здобуття.

Методика створення електронного навчального курсу - довготривалий та неоднозначний процес, який вимагає низки супровідних особливостей [8]. Передовсім, проєкт створення такого курсу передбачає визначення цільової аудиторії, для якого слухача призначений, хто формує попит на таку освітню пропозицію. Наступним кроком $є$ важливість передбачення часових рамок тривалості курсу та режим його проходження студентами (блоковий, модульний, загальнопідсумковий). Оскільки процес навчання передбачає мотивацію студентів до здобуття знань, то низка пізнавальних та соціальних мотивів повинна враховуватися у проєктуванні навчального електронного курсу.

Структура масових відкритих онлайн курсів передбачає [9]:

- проведення відеолекцій. Їхня тривалість обумовлюється часовими рамками до 7 хв, а весь навчальний курс розрахований на 4 год. Кожне лекційне заняття відображається візуалізацією аудіорозмови, передбачає анімаційні конструкції та елементи віртуальної реальності;

- виконання підсумкових інтерактивних завдань слухачами після завершення лекції. Їх самоціль моніторинг результату пізнавальної діяльності студентів та підсумкове узагальнення змісту лекції. Якщо завдання студентом не виконані, то, на жаль, долучення до подальшого лекторію буде припинено. Виконання цих завдань не $\epsilon$ довготривалим, проте передбачає “зворотний зв'язок” між викладачем та студентом;

- комунікативна взаємодія у навчальній спільноті (віртуальному кампусі) передбачає обговорення лекційного матеріалу 3 іншими слухачами лекторію і автором лекційного курсу. Залучаючи технічні можливості соціальних мереж (створюючи “закриті групи”), інших програм для віртуальної комунікації, спільнота слухачів 


\section{ПЕДАГОГІЧНІ УМОВИ ФОРМУВАННЯ ВІРТУАЛЬНОГО ОСВІТНЬОГО ПРОСТОРУ ЗАКЛАДУ ВИЩОЇ ОСВІТИ}

обговорює актуальні питання курсу. Для ефективності такого обговорення на форумах чи чатах необхідно залучати керівника курсу як експерта, зважаючи на його більш фахову компетентність щодо цих питаннь;

- аналіз дієвості курсу вимагає залучення цифрової педагогіки та педагогіки даних. Роблячи аналіз продуктивності та успішності навчального онлайн курсу, викладач проводить моніторинг переглядів навчально-методичного забезпечення курсу (відео-, аудіо-матеріалів; текстових ресурсів). Викладач зобов'язаний аналізувати організаційні складові на предмет дидактичної неуспішності, динаміки відвідуваності занять та кількості тих, хто завершив повний цикл навчання.

Методика створення навчальних онлайн курсів має особливості технічного, організаційного, прикладного значення. Такі курси є інновацією в академічному освітньому просторі, тому подальші дослідження їхніх організаційно-методичних засад $є$ актуальним.

Підкреслюючи цінність масових відкритих онлайнкурсів О. Скубашевська, виокремлює ризики пов'язані із навчанням в умовах віртуального простору [7, 140-150]:

1) широкий спектр освітніх послуг в інтернетпросторі може дезорієнтувати студента у правильному виборі. Відповідно, важлива добра репутація як освітньої онлайн платформи, так i університету, який пропонує навчальний курс;

2) завдяки інформативній базі даних інтернетпростору змінились підходи до навчання. Інформацію, особливо складнішого змісту, сучасна людина не запам'ятовує, зважаючи на можливості додаткового ресурсу онлайн допомоги. Проте цілковита довіра до істинності та науковості інформації в інтернеті невиправдана, що призводить до викривленості знань;

3) онлайн курс на освітніх платформах організаційно не передбачають співмірності у теорії та практиці. Невеликий відсоток практичних завдань не дає змоги цілком сформувати уміння та навички, тому важлива додаткова самостійна робота того, хто навчається. Відповідно, залишаються переваги за практикою у реальних умовах, де домінує досвід наставника і аналіз власних помилок.

Ефективна реалізація навчальних онлайнкурсів та навчального процесу загалом, в умовах віртуального освітнього простору, безпосередньо залежить від впровадження інноваційних методів та форм навчання. Зокрема, використанні електронних підручників, блогів (відеоблогів), вебінарів, соціальних медіа та геймифікації тощо. Особливий інтерес формує мультимедійна технологія геймифікації, яка передбачає включення елементів гри у навчальний процес, використовується при оцінюванні та організації змагань. Її поява на освітній платформі Coursera у 2012 р. у курсі “Gamification” (автор К. Вербах), забезпечила інноваційний погляд на дидактичні особливості навчальних онлайнкурсів. Передбачає візуальний анімаційний супровід, що, безумовно, позитивно впливає на формування рівня знань через унаочнення.

Віртуальний освітній простір передбачає використання віртуальних симуляторів та тренажерів (VR-технологіï). Дослідник VRтехнології Ю. Ткач визначає і характеризує їх так: технології віртуальної реальності “моделюються комп'ютером і розглядається в якості особливого інформаційного середовища, в якому всі об’єкти представлені в трьох вимірах. Відмінною рисою цього середовища є зміна зображень в режимі реального часу і переживання ефекту присутності. ВР імітує як вплив, так і реакції на цей вплив” [10, 310]. Такі технології підсилюють навчальну мотивацію та активність учнів, поліпшують формування знань через триєдине сприймання інформації “візуалізую - слухаю - дію” (зорові, слухові, моторні відчуття). Автор підкреслює, що “віртуальна реальність - це ідеальне навчальне середовищ”, а відповідні технології віртуальної реальності забезпечують оптимальний освітній результат через сприймання “когнітивної комп'ютерної графіки, головним завданням якої $є$ стимулювання пізнавальних механізмів, творчого мислення, а не однозначна інтерпретація знань" $[10,313]$. В. Климнюк виділяє типи освіти із залученням ВР: 1) денна освіта - передача навчального матеріалу через VR-технології; 2) дистанційна освіта - передбачає групове заняття із формуванням ефекту наявності навчальної спільноти; 3) “змішана освіта” відображається у можливості територіальної віддаленості в межах навчального приміщення, бачити події, взаємодіяти з реальними студентами та викладачем; 4) самоосвіта - для самостійного вивчення освітніх курсів може бути адаптований iз дотриманням VR-технологій [6, 209-210].

Такі технології $є$ нагальною освітньою потребою сьогодення, проте $є$ низка супровідних перешкод: висока вартість дидактичного обладнання, недостатня сформованість цифрової компетентності в учасників освітнього процесу, недослідженість методичних особливостей впровадження VRтехнології в освітній процес вищої школи.

Третьою педагогічною умовою є розвиток самостійної діяльності студентів в умовах віртуального освітнього простору. 


\section{ПЕДАГОГІЧНІ УМОВИ ФОРМУВАННЯ ВІРТУАЛЬНОГО ОСВІТНЬОГО ПРОСТОРУ ЗАКЛАДУ ВИЩОЇ ОСВІТИ}

Самостійна робота студента в умовах віртуального освітнього простору є визначальним чинником його успішності. За таких умов процес учіння / самонавчання має активний характер, де студент сам вибудовує індивідуальну освітню траєкторію, здобуваючи знання в межах не тільки формальної, а й неформальної освіти (ведення персональних блогів та телеграмканалів, участь в онлайнфорумах та навчальних спільнотах, перегляд вебінарів, відеолекцій тощо). Створення організаційно-методичного середовища викладачем, для здійснення самостійної навчально-пізнавальної діяльності студентом, має інноваційний характер, оскільки передбачає інші методи, засоби, форми самостійної роботи; не тільки інформаційнозмістову презентацію навчальних курсів, а й адаптацію до електронних навчальних платформ; переадресацію в інше навчальне середовище, можливість яких є доповнювального у розв'язанні освітніх завдань. Головною ознакою віртуального освітнього простору є комунікативна взаємодія із дотриманням зворотного зв'язку між викладачем та студентом. Відповідно, змінений підхід до організації самостійної роботи студента передбачає не тільки координуючу роль викладача в отриманні онлайн консультації, а й участь студента у форумах, обговоренні відповідних питань у соціальних мережах, чатах тощо, що виводить його за межі особистісного освітнього простору.

Самостійна робота студентів у віртуальному освітньому просторі вимагає навичок роботи в ньому. Серед них ми виокремлюємо такі: побудова суб'єктної взаємодії у віртуальному просторі, участь у віртуальних кампусах; ведення діалогу в онлайнрежимі віртуального простору; цифрова компетентність; пошук та обробка інформації в інтернет-ресурсах; письмового онлайн листування; самоконтроль та таймменеджмент в організації власного часу.

Отже, самостійна робота студента в умовах віртуального освітнього простору вимагає комплексної оцінки із педагогічних, психологічних та технічних засад.

Четвертою педагогічною умовою є готовність студентів до дистанційного (онлайн) навчання в умовах освітнього простору ЗВО.

Готовність до навчання в умовах освітнього простору слід розглядати через характер простору та суб'єктну взаємодію його учасників. Структура готовності студентів до навчальної діяльності в умовах віртуального особистісного простору відображається у таких компонентах:

1) мотиваційний - виражає ставлення студентів до навчальної діяльності в умовах дистанційного (онлайн) навчання освітнього простору;

2) операційний - визначає способи діяльності у застосуванні форм, методів, засобів навчання в умовах дистанційного (онлайн) навчання освітнього простору;

3) комунікативний - виражає систему комунікативну взаємодії між учасниками освітнього простору.

Фактори, які впливають на підвищення рівня готовності студентів до навчання в умовах дистанційного (онлайн) навчання освітнього простору: поглиблення мотивації; підвищення інтересу до навчання; комплектація інформаційної наукової бази, яка є передумовою для формування знань; урізноманітнення методів і форм дистанційного (онлайн) навчання та самостійної роботи в межах освітнього простору; комунікативна інтерактивна взаємодія між учасниками освітнього простору із дотриманням зворотного зв'язку.

Критеріями ефективності навчання студентів в умовах дистаниійного (онлайн) навчання освітнього простору $3 В О$ виступають: мотиваційний компонент (визначається пізнавальним інтересом та позитивним ставленням до навчання за таких умов); операційний компонент (визначається як практична готовність студентів до навчання на освітніх онлайн платформах); комунікативний компонент (реалізується в умінні побудувати комунікативну взаємодію, культурі усного і письмового онлайн спілкування).

Показники ефективності навчання студентів в умовах дистаниійного (онлайн) навчання освітнього простору $3 В О$ :

1) мотиваційна готовність студентів до навчання в умовах дистанційного (онлайн) навчання освітнього простору; до участі в навчальних електронних курсах як слухач; інтерес до навчання в умовах віртуальної реальності; самостійна робота студента у віртуальному навчальному процесі;

2) операційний компонент розглядається умінням володіти технологіями навчання в умовах дистанційного (онлайн) навчання освітнього простору та їх застосуванням, зокрема, здійснення навчальної діяльності у системі Moodle; залученням до навчання відеолекцій, вебінарів, відеоблогів, VR-технологій тощо;

3) комунікативна готовність студентів до побудови комунікативної та соціальної взаємодії, участь у віртуальних кампусах (навчальних спільнотах), обговорення навчальних тем на форумах та соціальних мережах.

Визначення структурних компонентів, критеріїв і показників готовності студентів до 


\section{ПЕДАГОГГЧНІ УМОВИ ФОРМУВАННЯ ВІРТУАЛЬНОГО ОСВІТНЬОГО ПРОСТОРУ ЗАКЛАДУ ВИЩОЇ ОСВІТИ}

навчання в умовах дистанційного (онлайн) навчання освітнього простору дає змогу сформувати рівні готовності (низький, середній, високий (творчий), які визначають наявність чи відсутність показників.

Висновки і перспективи подальших досліджень. Визначені педагогічні умови формування віртуального освітнього простору ЗВО розкривають організаційно-методичні засади означеної освітньої системи відповідності до оптимальної організації саморозвитку (самопізнання, самовизначення, самоуправління, самоудосконалення, самореалізація) студента. Можливість подальшого обгрунтування інших педагогічних умов формування віртуального освітнього простору ЗВО, згідно зі змістовими, дидактично-процесуальними та методичними особливостями, розкриває характер подальших досліджень. Проте актуальність та інноваційність феномену “віртуальна освіта / простір / навчання” окреслює багатоаспектність дослідження через інституційні, функціональні та прикладні підходи.

\section{ЛІТЕРАТУРА}

1. Галкина О. В. Роль и место понятия “организационно-педагогические условия” в терминологическом аппарате педагогической науки : автореф. дисс. на соиск. уч. степени канд. пед. наук : спец. 13.00.01 “Общая педагогика, история педагогики и образования”. Самара, 2009. 19 c. URL: http://www.dissercat.com/content/ r o l - i - m e s t o - p o n y a t i y a organizatsionnopedagogicheskie-usloviyaterminologicheskom-apparate\#ixzz349LHX8B7.

2. Гора Н. В. Педагогічні умови формування професійної компетентності майбутніх товарознавців. “Молодий вчений”. № 6 (58) червень, 2018 р. С. 134-137.

3. Грінченко М. С. Значення віртуального простору у професійній підготовці майбутнього соціального педагога. Вісник Черкаського університету. Серія педагогічна. № 24., 2014. С. 29-36.

4. Демент М. О. Створення сприятливого освітнього простору для курсантів ДСНС України. Збірник наукових праць "Педагогіка та психологія”. Харків. Вип. 58, 2017. С. 79-89.

5. Срмаченко В. Є., Дериховська В. І. Особливості трансформації світової системи вищої освіти у XXI столітті. Мукачівський дердавний університет. Вип. 10. 2017. С. 518-522.

6. Климнюк В. Є. Віртуальна реальність в освітньому процесі. Зб. наук. пр. Харківського національного університету Повітряних Сил. № 2, 2018. C. 207-212.
7. Скубашевська О. С. Масова відкрита онлайн освіта як можливість навчання протягом життя. Науковий вісник ХНПУ. Серія “Філософія”. Вип. 46. 2016. С. 140-150.

8. Сегол Р. Університет майбутнього: Онлайносвіта та змішане навчання. URL: https:// www.youtube.com/watch? $v=b 1-p-3 \quad Q-5 I$ (дата звернення: 10.11.2020).

9. Сегол Р. Як навчатись онлайн і нічого не впустити. URL: https://www.youtube.com/ watch?v=EAEnK1ss6yo (дата звернення: 10.11.2020).

10. Ткач Т. В. Психологічні засади проектування освітнього простору особистості: автореф. дис. ... д-р псих. наук: 19.00.07. Київ, 2010. 50 с.

\section{REFERENCES}

1. Halkina, O.V. (2009). Rol i mesto ponyatiya "organizatsionno-pedagogicheskie usloviya" v terminologicheskom apparate pedagogicheskoy nauki [The role and place of the concept of "organizational and pedagogical conditions" in the terminological apparatus of pedagogical science]. Extended abstract of candidate's thesis. $19 \mathrm{p}$. Available at: http://www.dissercat.com/content/rol-i-mestoponyatiya-organizatsionnopedagogicheskie-usloviyaterminologicheskom-apparate\#ixzz349LHX8B7. Name from the screen.[in Russian].

2. Hora, N.V. (2018). Pedahohichni umovy formuvannia profesiinoi kompetentnosti maibutnikh tovaroznavtsiv [Pedagogical conditions of formation of professional competence of future commodity experts]. "The Scientists Journal". No. 6 (58) June. pp. 134-137.[in Ukrainian].

3. Hrinchenko, M.S. (2014). Znachennia virtualnoho prostoru u profesiinii pidhotovtsi maibutnoho sotsialnoho pedahoha [The importance of virtual space in the training of future social pedagogue]. Bulletin of the Cherkassy university. Series pedagogy. No. 24, pp. 29-36.[in Ukrainian].

4. Dement, M.O. (2017). [Formation of the Readiness of the Future Officer of the Ministry for Emergencies to Professional Activity in Modern Conditions]; Collection of scientific works "Pedagogy and Psychology". Vol.58. Kharkiv, pp. 7989. [in Ukrainian].

5. Yermachenko, V.Ye. \& Derykhovska, V.I. (2017). Osoblyvosti transformatsii svitovoi systemy vyshchoi osvity u XXI stolitti [Peculiarities of transformation of the world system of higher education in the XXI century]. Mukachevo State University. No.10. pp. 518-522. [in Ukrainian].

6. Klymniyk, V. Ye. (2018). Virtualna realnist v osvitnomu protsesi [Virtual Reality in Educational Process]. Collection of Scientific Works of Kharkiv 
National Air Force University. No. 2. pp. 207-212. [in Ukrainian].

7. Skubashevska, O.S. (2016). Masova vidkryta onlain osvita yak mozhlyvist navchannia protiahom zhyttia [Mass online education as an opportunity for lifelong learning]. Scientific Journal of KhNPU. Philosophy series. No.46. pp. 140-150. [in Ukrainian].

8. Segol, R. (2020). Universytet maibutnoho: Onlain-osvita ta zmishane navchannia [University of the Future: Online Education and Blended Learning]. Available at: https://www.youtube.com/watch?v=b1-
p-3_Q-5I (Accessed 10 Nov. 2020). [in Ukrainian].

9. Segol, R. (2020). Yak navchatys onlain i nichoho ne vpustyty [How to study online and miss nothing]. Available at: https://www.youtube.com/ watch? $v=$ EAEnKlss6yo (Accessed 10 Nov. 2020). [in Ukrainian].

10. Tkach, T.V. (2010). Psykholohichni zasady proektuvannia osvitnoho prostoru osobystosti [Psychological principles of designing the educational space of the individual]. Extended abstract of Doctor's thesis. Kyiv, 50 p. [in Ukrainian].

Стаття надійшла до редакції 10.08.2021

УДК 373.2.015.31:7

DOI:

Надія Дудник, кандидат педагогічних наук, доцент кафедри загальної педагогіки та дошкільної освіти Дрогобицького державного педагогічного університету імені Івана Франка

\section{ПЕДАГОГІЧНІ НОВАЦІЇ В ЕСТЕТИЧНОМУ ВИХОВАННІ ДІТЕЙ СТАРШОГО ДОШКІЛЬНОГО ВІКУ}

У статті розкривається сутність таких понять, як естетика, естетичне виховання, народознавча культура, сенсорне виховання. Основна увага відведена виокремленню проблеми необхідності зосередження уваги педагогів на естетичному вихованні дітей раннього та дошкільного віку в умовах ЗДО. Проаналізовано дослідження сучасних науковців щуодо особливостей впливу естетичної культури на загальний розвиток дитини. Подано для обговорення проблему виховання дітей дошкільного віку з позиції формування естетичної культури та знань й умінь у народознавчій сфері. Виокремлено проблему професійного саморозвитку педагогів ЗДО у естетичному розвитку через участь у творчих майстер-класах, художньо-естетичних заходах, практичній демонстрації своїх талантів у процесі організації освітнього процесу з дошкільниками як на спеціальних заняттях, так і в опосередкованих вправах, де вміння поєднувати знання і вміння у мистецькій галузі мають місие у життєдіяльності вихованців. Подано перспективу педагогічного впливу на процес естетичного виховання з використанням альтернативних, авторських мистецьких програм, які сприяють творчому розвитку педагогів, дошкільників та батьків вихованців.

Ключові слова: естетичне виховання; народознавче виховання; творчий розвиток; сенсорне виховання; мистецтво; діти дошкільного віку.

Jim. 10.

Nadiya Dudnyk, Ph.D.(Pedagogy), Associate Professor of the General Pedagogy and Preschool Education Department Drohobych Ivan Franko State Pedagogical University

\section{PEDAGOGICAL INNOVATIONS IN AESTHETIC EDUCATION OF PRESCHOOL CHILDREN}

The article reveals the essence of such concepts as aesthetics, aesthetic education, ethnographic culture, sensory education. The main attention is paid to highlighting the problem of the need to focus pedagogues on the aesthetic education of children of early and preschool age in the conditions of PEI. The research of modern scientists on the peculiarities of the influence of aesthetic culture on the general development of the child is analyzed. The problem of educating preschool children from the standpoint of the formation of aesthetic culture and knowledge and skills in the field of ethnography is presented for discussion. The aim of the article is to find ways to combine the achievements of technical and informational progress with the need to practically involve children in the development of knowledge of the art of music, art, dance, poetry, theater, which has a cultural content and national characteristics. The problem of professional self-development of PEI pedagogues in aesthetic development through participation in creative master classes, artistic and aesthetic events, practical demonstration of their talents in the process of organizing the educational process with preschoolers both in special classes and in indirect exercises, where the 